\title{
How Cultural Divergence Influences Expatriate's Performance in Malaysia
}

\section{Umme Salma Sultana, ${ }^{1,3}$,Tarnima Warda Andalib², and Mohd Ridzuan Darun ${ }^{3}$}

${ }^{1}$ Faculty of Business Management and Professional Studies, Management and Science University, 40100, Shah Alam, Selangor, Malaysia

${ }^{2}$ School of Management, Universiti Sains Malaysia, Georgetown,11800, Pulau Pinang, Malaysia

${ }^{3}$ Faculty of Industrial Management, Universiti Malaysia Pahang, Lebuhraya Tun Razak, 26300 Gambang, Pahang, Malaysia

\section{Abstract}

Malaysia is one of the countries which welcome expatriates from all over the world to fill the need for skilled employees. This paper provides an overview of how cultural divergence influence expatriates performance in Malaysia. The main purpose of this study is to identify the important issues which directly or indirectly, positively or negatively influence expatriate's performance in day to day work. This study reviewed

Corresponding Author: Umme Salma Sultana umme_salma@msu.edu.my

Received: 5 August 2019 Accepted: 14 August 2019 Published: 18 August 2019

Publishing services provided by Knowledge E

(c) Umme Salma Sultana et al. This article is distributed under the terms of the Creative Commons Attribution License, which permits unrestricted use and redistribution provided that the original author and source are credited.

Selection and Peer-review under the responsibility of the FGIC2019 Conference Committee.
55 papers related to cultural divergence, employee performance, cultural intelligence, and human resource management practices in Malaysia. The finding highlights that expatriates experience cultural clashes between foreign and local values, which pose direct influences on expatriates' performance. This study contributes to the body of knowledge in the cross-cultural management field as well as practical implications to expatriating firms. Finally, this research is beneficial and informative, especially for Malaysian researchers and managers in International Human Resource Management (IHRM) field.

Keywords: cultural divergence, expatriates in Malaysia, job performance, human resource management.

\section{Introduction}

Culture can be referred to as a collection of attitudes and beliefs that affects individual behaviors and views. In an organization, the employees' work culture influence their job performance and working styles, especially for expatriates. Previous researchers believed that it is vital for a leader in a company to understand the importance of culture in his organization (Ramlan, Abashah, Samah, Rashid, \& Radzi, 2018). Unlike the legal environment and political views, cultural borders cannot be easily removed. This is because, just like identity, culture is an essential part of an individual which is learned and assimilated into oneself through the environment. When people from 
differences in behaviors, values, and ethics. Therefore, a strong control of managerial power is important in ensuring that employees can work together harmoniously despite their cultural differences. To become successful in today's challenging and competitive environment, an organizational manager who can see beyond surface-level cultural differences is of the necessity (Jyoti \& Kour, 2015). Inability to overcome the cultural borders may result in poor business performance, ineffective communication among employees, and low job involvement.

In the obtained literature, the authors have defined an 'expatriate' as an individual who is assigned to work and live in a foreign country (Tahir \& Ismail, 2007). The expatriate contributes a significant part in "maintaining the organizational structure and philosophy of multinational corporations (MNCs) while following the rules and regulations of work within the host country" (Ghemawat \& Reiche, 2011). In the private sector, the expatriate managers are mostly positioned in MNCs while in the public sector, they are primarily positioned in diplomatic posts.

\subsection{Background of the study}

For multinational firms, expatriates play important roles that help to expand their operations and connections. Due to this significant contribution of expatriates, the number of expatriates has increased dramatically over the years (Harvey \& Moeller, 2009). In order to ensure the success of this program, the leader of an organization must oversee the performance of their expatriate employees. Previously, numerous studies on expatriates have been conducted in many countries, including Nigeria, Spain, and Bangladesh. Due to the limited literature available on Malaysians context, this research intends to focus on expatriates' issues in Malaysia.

\subsection{Research Problem}

Previous studies have demonstrated that expatriates often face difficulties in adapting to a new place with a vastly different culture from their native countries. These adaptations in terms of lifestyle changes are required to ensure that they can perform their best as an employee in a foreign organization ( $\mathrm{Ng}$, Wang, \& Chan, 2017; Ward, Bochner, \& Furnham, 2005; Ward \& Rana-Deuba, 2000; Warren, 2017). There are a few core factors or challenges that expatriates face from time to time everywhere in the world. In Malaysia, expatriates also do face and feel certain factors, which cannot be ignored 
and must be carefully observed and discussed thoroughly. This circumstance instigates some apparent questions and searches throughout the study.

\subsection{Research Questions}

This review paper seeks to address the following questions:

1. What are challenges faced by the expatriates regarding the differences in culture?

2. How cultural divergence influences expatriate's performance in Malaysia?

3. How the expatriates adapt to cross-cultural differences in the country?

Despite numerous researches conducted on this topic, there is limited reliable information available at the moment according to the Malaysian context. Hence, the results of this study are of the essence to contribute to the existing knowledge on the topic of expatriate's management in Malaysia. Additionally, it is aimed to create awareness regarding cross-cultural adjustments among employees according to the Malaysian context.

\subsection{Research Objectives}

In general, the scope of this review is to investigate the extent of cultural divergence in affecting the expatriates' performances in Malaysia. The following are the specific objectives:

1. To assess the challenges that are experienced by the expatriates.

2. To determine core components that influence the expatriates' performances.

3. To determine the expatriates' adjustment factors in Malaysia.

4. To study how expatriates' performances can be enhanced by cross-cultural training and adjustment programs.

5. To establish the effects of culture, adjustment patterns, and security on expatriates' success.

6. To examine the expatriates' satisfaction regarding the level of support from organizations and how this affects their commitment to their assignments. 
This research paper is divided into six sections. Following the introductory section, Section 2 presents an in-depth review of papers related to cultural divergence, employee performance, cultural intelligence, and human resource management practices in Malaysia. The methodology of this research is explained in Section 3. Next, the findings of this research are presented in Section 4 and are discussed in details in Section 5. Finally, the last section provides the conclusions and implications of the study.

\section{Literature Review}

\subsection{Culture}

In general, previous researchers have described culture as a shared collection of personality traits, views, and beliefs in a society (Deari, Kimmel, \& Lopez, 2008). In their study, Wang et al. (2009) have reported that culture is a form of value "are manifested in practices, behaviors, and various artifacts shared by members of an organization or a nation." In a society, culture helps to shape the behavior and characteristics of the members (Ramlan et al., 2018; Shafiq \& Qureshi, 2014; Zaman, Qureshi, \& Bhatti, 2011). From the corporatist perspective, the differences in cultural background and values influence one's working style, such as communication skills, time management, body language, and problem solving (Ramlan et al., 2018). Furthermore, culture is vital because it also influences one's job performance and satisfaction (Ramlan et al., 2018; Shafiq \& Qureshi, 2014; Zaman, Qureshi, \& Bhatti, 2011). Hence, it is imperative for the management to show initiatives in understanding the employees' cultural differences as this will result in better management style, facilitating communication, developing effective reward systems, and improving the performance of the company as a whole (Ramlan et al., 2018).

\subsection{Expatriation in Malaysia}

Expatriation is not an uncommon practice in Malaysia. For the past decade, the country has experienced three distinctive phases of incoming expatriates. Initially, the earliest group of expatriates that came to Malaysia was the Britons who served in the private sectors, such as $\mathrm{ICl}$, Harrison and Crosfield, Shell, Guthries, British Petroleum, and Dunlop. In the government sector, they are primarily playing the roles of technical specialists, diplomats, advisors, and academics (Rostamzadeh, Anantharaman, \& Tong, 
2012; Shephard, 1996). The second wave was represented by expatriates from the United States of America and other European countries who were placed in global organizations. Several gigantic organizations that are involved in expatriation including, Siemens, Esso, Nestle, Phillips, and Volvo. Finally, Malaysia accepted the visits of Asian managerial expatriates from Europe and America (Jatmiko, 2018; Rostamzadeh et al., 2012; Shephard, 1996; Tahir \& Ismail, 2007). This final expatriation wave has inspired our government to adopt the "Look East" policy in the 1980s. This decision was also influenced by the enhancement of our country's electronics industry and close relationships between Malaysia and Australia and the Newly Industrialized Asian countries (Jatmiko, 2018; Rostamzadeh et al., 2012; Shephard, 1996; Tahir \& Ismail, 2007).

Interestingly, expatriates often gain new experiences and stand a chance of adopting a different lifestyle, especially when the cultures in a new environment differ vastly from their home country. In order to thrive in a challenging work atmosphere, expatriates need to adapt to their surroundings. This changes may pose as a source of distress for some individuals since the changes involve time, energy, and financial sacrifices. Without perseverance and passion towards ones' profession and job responsibilities, it is difficult for them to stay committed in their career. Hence, it is understandable that there are expatriates who had to reconsider staying in the foreign country due to the differences in culture (Aycan, 1997; Berry, Berry, Poortinga, Segall, \& Dasen, 2002; Gelfand, Erez, \& Aycan, 2007). Furthermore, several studies on expatriation have indicated that people from different cultures may encounter challenges in understanding each other's' views and behaviors, which may result in "cultural clash" (Elashmawi, 2000).

\subsection{Cultural Intelligence}

One of the previous studies has defined cultural intelligence as an individual's capability in interacting with people from a different culture effectively. This particular concept consists of several constructs, namely meta-cognitive, cognitive, motivational, and behavioral dimension (Earley \& Ang, 2003). The first dimension is meta-cognitive cultural intelligence, which refers to one's awareness, knowledge, or ability to process information relating to culture (Ang, Van Dyne, \& Koh, 2006). According to Ang et al. (2006), individuals with this ability tend to think critically and express concerns about cultural assumptions. Capabilities that are relevant to this cultural intelligence are revising and observing the cultural models for a particular society or country. These capabilities are useful in generating coping strategies ( $\mathrm{Ng} \&$ Earley, 2006). 
The next dimension is the cognitive cultural intelligence which reflects one's knowledge on the conventions and norms of different cultures (Ang et al., 2006). This includes knowledge of the cultural values, social systems, legal, and economic aspects of a certain culture. Individuals with high cognitive cultural intelligence are capable of differentiating and appreciating the uniqueness of other people's cultures (Ramlan et al., 2018).

The third dimension is the motivational cultural intelligence. This construct is considered to be exceeding the boundaries of merely recognizing cultural differences. Ang et al. (2006) have described motivational cultural intelligence as one's interest in engaging with another culture. Interestingly, this feature of cultural intelligence motivates an individual to adapt to a new cultural setting (Earley \& Ang, 2003; Ng \& Earley, 2006). This third dimension includes three main motivators: self-enhancement, self-growth and improvement, and life continuity (Earley \& Ang, 2003).

The final aspect is the behavioral dimension, which involves the ability to exhibit adaptive behaviors for the appropriate cultural settings. According to Earley and Ang (2003), individuals with high behavioral cultural intelligence tend to use politically and socially acceptable words, facial expressions, tone, and gestures.

The overview of available literature showed that cultural intelligence has been connected with expatriates' work behaviors such as task performance (Ang et al., 2006; Ang et al., 2007), cultural judgment and decision-making (Ang et al., 2006), and cultural adaptation (Ward, Fischer, Zaid Lam, \& Hall, 2009).

\subsection{Job Performance}

In theory, individual job performance can be described as a function of abilities, aspiration, and knowledge which influence one is expected behavior that is relevant to a company's goals, such as formal job responsibilities (Campbell, 1999). As proposed by Borman and Motowidlo (1993), job performance consists of two dimensions, which are task dimension and contextual dimension. Also known as "in-role," task dimension is a construct that is driven by deadlines. On the other hand, the contextual dimension or "extra-role" is sometimes seen as a discretionary construct. This theory is commonly applied in an international setting (Caligiuri, 1997). Numerous studies have been conducted to investigate the relationship between cultural intelligence and job performance (Ang et al., 2006; Ang et al., 2007; Rose, Sri Ramalu, Uli, \& Kumar, 2010; Lee \& Sokoco, 2010). These studies have concluded that cultural intelligence significantly influences job performance. 
Conforming the role expectations is a crucial aspect in assessing one's job performance (Ramalu, Rose, Uli, \& Kumar, 2012). At the workplace, expatriates may receive greater expectations in terms of job performance from their superiors and fellow workers. On top of the aforementioned constructs, international assignees are also expected to achieve particular tasks such as transferring knowledge and technology to the locals (Ghemawat \& Reiche, 2011). Unfortunately, expatriates are often perceived as having poor job performance when they have a different cultural background, fail to meet the role expectations, and unable to understand cultural differences in role expectations (Stone-Romero, Stone, \& Salas, 2003). This situation is more common among individuals who are working in an unfamiliar culture and work environment, which are vastly different from the host country. Since expectations for performing role prescribed behaviors often differ across cultures, cultural intelligence will help individuals to do in their tasks more effectively.

\subsection{Job Satisfaction}

Despite its wide usage in scientific research, the whole body of the research community has not accepted the exact definition of job satisfaction. This is because different authors have varying approaches and perspectives in defining this terminology. Job satisfaction can be defined as any combination of physiological, environmental, and psychological circumstances that influence one's level of satisfaction towards their work (Hoppock, 1935). Another researcher defined job satisfaction as individuals' attitudes (George et al., 2008), orientations (Vroom, 1964), level of contentment (Statt, 2004), behavior (Davis et al.,1985) and feelings (Armstrong, 2006) toward their current work roles. Earlier studies have indicated that employees' job satisfaction is often affected by their material and psychological needs (Aziri, 2008) such as their relationships with coworkers and employers, work roles and responsibilities, salary (George et al., 2008) and sense of achievement (Mullins, 2005). These factors, both intrinsic and extrinsic, may result in either positive or negative perceptions, ranging from extreme satisfaction to extreme dissatisfaction. When an employee shows desirable behaviors and positive looks towards their job, this indicates job satisfaction, and vice versa (Armstrong, 2006).

One's satisfaction towards their work is important because according to Kaliski (2007), job satisfaction is a vital element that drives employees to achieve career advancement, better income, recognition, and personal sense of fulfillment. Moreover, it is also linked to ones' personal well-being, mental health, and work productivity (Kaliski, 2007). To sum, when an employee is content with his career roles and displays a positive attitude 
towards his work, he is more likely to performs his best in playing his roles. Ultimately, this will benefit the organization by enhancing the organization's efficiency, reputation, and productivity.

\subsection{Innovation Performance}

Since the early twentieth century, innovation has been seen as a vital aspect that helps an organization to thrive. In general, many researchers in the economic and business literature have agreed that innovation can simply be described as something new (Hauschildt \& Salomo, 2007; Kotler \& de Bes, 2003; Littkemann \& Holtrup, 2008; Porter, 1990; Rogers, 2003; Schumpeter, 1912; Valenta, 1969; Whitfield, 1975). According to Schumpeter's theory, innovation has been defined as the introduction of a novel or improved process, products, or methods that can be implemented in a certain organization or business practices (OECD, 2005).

Innovative capability is regarded as the main element that supports enterprises' performance and competitiveness (Andergassen, Nardini, \& Ricottilli, 2009). Numerous studies have indicated that there is a relationship between innovative capability and innovation market success (Baden Fuller \& Pitt, 1995; Barker III \& Duhaime, 1997; Christensen \& Raynor, 2003; Drucker, 1999; Epstein, Davila, \& Matusik, 2004; Markides, 1997; Nicolescu \& Nicolescu, 2012; Tushman \& Anderson, 2004). This correlation is accepted widely by many researchers because, in order to maintain the company's great reputation and success in a competitive environment, the company has to implement systemic innovation. By managing the process differently than the next company and continually making new changes through innovative capability, this allows the company to come out on top (Fiorentino, 2010). For instance, small- and medium-sized enterprises (SMEs) can innovate and respond to their clients' needs more efficiently due to their less complex organizational and administrative systems (Audretsch, 2003; Zeng, Xie, \& Tam, 2010).

Overall, we can see that a company's ideal objective is to turn innovation inputs (innovation capability) into lucrative outputs (market implementation). This conversion can be termed as innovation performance. In short, innovative performance is an inclusive construct that oversees the processes from all stages, starting from research and development (R\&D), patenting, up to the product introduction, without assuming the economic success of innovations (Ernst, 2001; Stuart, 2000). Unfortunately, a majority of organizations do not take innovation performance into account, despite the significance of innovation in enhancing organizations growth (Skarzynski \& Gibson, 2008). 
Previous findings have shown a continual dedication is necessary in order to ensure the company's sustainable innovation efforts (Davila, Epstein, \& Shelton, 2013).

\subsection{Employees' Rights}

For decades, the rights of a human being has been a major issue in the industrial sector. In the olden days, employees were treated as slaves with little to no recognition and appreciation from the employer. Fortunately, a few decades ago, people have started to gain awareness on employees' rights, and revolutionary concepts and standards have been improvised.

According to Andalib and Darun (2018), a few universal standards have been established where employee rights are significantly mentioned and nurtured, which are the Universal Declaration of Human Rights14 and International Labour Organization (ILO). These standards have presented some basic protocols, which are significantly important for employees who are fighting for their rights. In this study, the Universal Declaration of Human Rights14, ILO protocols, conventions, and articles were analyzed. The articles have discussed rights to life, right to liberty, right to choose work based on workplace condition, remuneration, sanitation right to receive permanent and long-term benefits in addition to the regular ones.

\section{Methodology}

This paper aims to investigate the core components of cultural divergences by analyzing and reviewing 50 published articles and scholarly works. Data were collected from various sources using standard techniques. Andalib et al. (2018) have stated that this methodology can be considered as systematic qualitative analysis since philosophical paradigms with the interpretative technique have been used to summarize relevant information.

\subsection{Steps of Data Collection}

In the current study, data were collected and analyzed by following these steps:

1. A computerized database search was performed using Proquest, Emerald, and Elsevier. 
2. The literature search was conducted by using the specified keywords: cultural divergence, expatriates in Malaysia, job performance, human resource management.

3. All articles found were stored in NVIVOMac tool.

\subsection{Analyze Data}

According to Andalib (2018), NVIVOMac serves as a reliable platform to analyze any data. In this study, reports or scholarly papers were stored, sorted, and analyzed through NVIVOMac. Before data analysis was conducted, several selection steps were taken:

1. Categorizing articles by external and internal components.

2. Highlight and run the articles by keywords.

3. Derive components from NVIVO tool.

4. The prioritized components are highlighted and carefully observed to draw the result subjectively.

\section{Results}

Categorizing and grouping the components have been done based on soft coding that validates and justifies data with generalizability (Andalib, 2018; Auerbach \& Silverstein, 2013). The findings were extracted from published articles and summarized systematically to aid comparison. Data regarding the challenges faced by expatriates are presented in Table 1.

Next, Table 2 presents the data extracted from published articles on the impacts of cultural divergence. Findings show that the core components are local culture, cultural intelligence, and cultural intelligence with job performance.

\section{Discussion}

Several significant components are found in this paper, which reveals the impacts on expatriates' performance in Malaysia. Based on the data collected, six challenges faced by expatriates have been determined. These six components are the impact of local culture (LC), cultural intelligence (Cl), job performance (JP), job satisfaction (JS), innovation performance (IP) and employees' rights (ER). Researchers' have followed 
TABLE 1: Challenges faced by expatriates in Malaysia.

\begin{tabular}{|c|c|c|c|c|}
\hline $\begin{array}{l}\text { Scholars' } \\
\text { References }\end{array}$ & Challenges & Problems faced & Solutions & $\begin{array}{c}\text { Rate Experience } \\
\text { (Good/Moderate/ } \\
\text { Bad) }\end{array}$ \\
\hline $\begin{array}{l}\text { Heirsmac \& Agwu } \\
\text { (2015) }\end{array}$ & Foreign language & $\begin{array}{l}\text { Bahasa Malayu is } \\
\text { widely used when } \\
\text { communicating with the } \\
\text { expatriates. }\end{array}$ & $\begin{array}{l}\text { More usage of } \\
\text { English is } \\
\text { required. }\end{array}$ & Moderate \\
\hline Guardian (2013) & Security & $\begin{array}{l}\text { Most areas are safe } \\
\text { except for some suburb } \\
\text { areas. }\end{array}$ & $\begin{array}{l}\text { Monitoring } \\
\text { devices can be } \\
\text { used as } \\
\text { surveillance to } \\
\text { increase security. }\end{array}$ & Good \\
\hline Muniapan (2015) & Racial & $\begin{array}{l}\text { Negative interracial } \\
\text { interactions have been } \\
\text { observed. }\end{array}$ & $\begin{array}{l}\text { A more } \\
\text { harmonious } \\
\text { interaction must } \\
\text { be instilled at } \\
\text { workplace. }\end{array}$ & Bad \\
\hline Muniapan (2015) & $\begin{array}{l}\text { Employees' } \\
\text { (Labours' rights) }\end{array}$ & $\begin{array}{l}\text { Expatriates are } \\
\text { discriminated as } \\
\text { flexible working hours } \\
\text { are applied for locals } \\
\text { only. Conversely, } \\
\text { expatriates have long } \\
\text { working hours with low } \\
\text { income. }\end{array}$ & $\begin{array}{l}\text { The } \\
\text { implementations } \\
\text { of UDHR and ILO } \\
\text { are necessary. }\end{array}$ & Bad \\
\hline $\begin{array}{l}\text { Heirsmac \& Agwu } \\
\text { (2015) }\end{array}$ & Cultural shock & $\begin{array}{l}\text { Expatriates have to } \\
\text { deal with preconceived } \\
\text { or prejudiced cultural } \\
\text { issues. }\end{array}$ & $\begin{array}{l}\text { Racial or cultural } \\
\text { stereotypes must } \\
\text { be eliminated. }\end{array}$ & Moderate \\
\hline
\end{tabular}

TABLE 2: Impacts of variables on expatriates' performances, extracted from previous scholarly works. Data are presented following Miles, Huberman, and Saldana (2014) technique where the impacts have been analyzed by ranges: Positive (++); Negative (+); Mixed (\#).

Expatriation in Malaysia (EM)
Impact of Local Culture (LC)
Cultural Intelligence (Cl)
Job Performance (JP)
Job Satisfaction (JS)
Innovation Performance (IP)
Employees' Rights (ER)

\begin{tabular}{c} 
LR of Malaysia \\
\hline$\#$ \\
\hline++ \\
++ \\
\hline$\#$ \\
+ \\
\hline$\#$ \\
\hline
\end{tabular}

\begin{tabular}{c} 
LR of Asia \\
\hline++ \\
++ \\
$\#$ \\
$\#$ \\
+ \\
$\#$ \\
\hline
\end{tabular}

\begin{tabular}{|c|}
\hline $\begin{array}{c}\text { Other Western } \\
\text { LRs }\end{array}$ \\
\hline+ \\
\hline$\#$ \\
\hline \# \\
\hline+ \\
\hline \# \\
\hline++ \\
\hline
\end{tabular}

miles, Huberman and Saldana (2014) technique to analyze and explain the variables' influences and impacts.

According to the findings, the local culture poses mixed impacts on expatriates' performance in Malaysia, while globally, it has a negative impact. Interestingly, the impact of local culture has a positive result on expatriates' performance in Asia. The result shows that from the literature, it is clear that the impact of cultural divergence has a positive impact on expatriate performance living in Malaysia and overall Asia. 
Next, we can see that job performance is positively influenced by cultural diversity in Malaysia. However, cultural diversity has a mixed impact on expatriates' job satisfaction in Malaysia and Asia. Meanwhile, this variable has a negative impact on western countries. According to the result, cultural diversity has a negative impact on innovation performance in Malaysia and Asia. Last but not least, employees' rights have posed a mixed result in Malaysia and Asia. Interestingly, it receives a positive result globally. As per Andalib et al. (2019) the eastern influences are significantly distinct than that of western influences because of the cultural and religious dimensions. The other challenges faced by the expatriates in Malaysia are distinct as well, mainly because of the three parallel races with distinct three local practiced languages and practiced distinct religions that lead to various dimensional cultural practices as well. The constant maintenance of constitutional and religious bars together itself is a difficult task. Therefore, keeping pace with various foreigners' dimensions are also quite interesting and difficult from various organizations' perspectives. The expatriates through face these challenges like cultural shock, racial distinctions, security issues, and language barriers in Malaysia; expatriates also experience feelings of brotherhood, flexible timing, leisure family hours, etc.

\section{Conclusion and Implications}

With the completion of this study, the researchers believed that the aforementioned research objectives have been achieved. This study aims to enhance our knowledge of how cultural divergence influences expatriates' performance in Malaysia. By knowing the effects of cultural differences on their performance, this allows the company managers to gain insights on the aspects that can be improved at the workplace to accommodate the expatriates physical, physiological, and social needs. Besides, this study highlights the expatriates' perceptions and the challenges that they face in experiencing cultural divergence. The expatriate and the host nation should more aware and receptive towards the differences. To lessen the challenges, awareness of cultural differences should be instilled among the expatriates and the employee in the host nation. This can be achieved by introducing a cross-cultural training program. Looking into the future, it is suggested to be taken into account to conduct that comparative studies on the expatriates' adjustment and adaptation process while serving in Malaysia. Also, the challenges and adjustments experienced by the expatriates' family members should be included in future research. 


\section{References}

[1] Ang, S., Van Dyne, L., \& Koh, C. (2006). Personality correlates of the four-factor model of cultural intelligence. Group \& Organization Management, 31(1), 100-123.

[2] Ang, S., Van Dyne, L., Koh, C., Ng, K. Y., Templer, K. J., Tay, C., \& Chandrasekar, N. A. (2007). Cultural intelligence: Its measurement and effects on cultural judgment and decision making, cultural adaptation and task performance. Management and Organization Review, 3(3), 335-371.

[3] Andalib, T. W. \& Darun, M. R. (2018). An HRM framework for manufacturing companies of Bangladesh mapping employee rights' protocols and grievance management system. Indian Journal of Science and Technology, 11, 17

[4] Andalib, T. W., Darun, M. R., \& Azizan, N. A. (2019). East Asian trends of human resources management: Theories and practices. International Journal of Human Resources Development and Management.

[5] Andalib, T. W. (2018) A study on convergence of international employee rights within human resources management practices in Bangladesh (Doctoral dissertation), Universiti Malaysia Pahang.

[6] Auerbach, C. F., \& Silverstein, L. B. (2003). An introduction to coding and analysis: QUalitative Data New york and London: New York University Press.

[7] Aycan, Z. (1997). Expatriate adjustment as a multifaceted phenomenon: Individual and organizational level predictors. International Journal of Human Resource Management, 8(4), 434-456.

[8] Berry, J. W., Berry, J. W., Poortinga, Y. H., Segall, M. H., \& Dasen, P. R. (2002). Crosscultural psychology: Research and applications: Cambridge University Press.

[9] Borman, W. C., \& Motowidlo, S. (1993). Expanding the criterion domain to include elements of contextual performance. Personnel Selection in Organizations; San Francisco: Jossey-Bass, 71.

[10] Caligiuri, P. M. (1997). Assessing expatriate success: Beyond just. Being There”. In D. M. Saunders \& Z. Aycan (Eds.), New Approaches to Employee Management. 4, 117-140.

[11] Campbell, J. P. (1999). The definition and measurement of performance in the new age. Pulakos (Eds.), The changing nature of performance: Implications for staffing, motivation, and development, 399, 429.

[12] Cooke, F. L. (2009), A decade of transformation of HRM in China: A review of literature and suggestions for future studies, Asia Pacific Journal of human resources, 47, 1. 
[13] Davila, T., Epstein, M., \& Shelton, R. (2013). Making Innovation Work: How to Manage It, Measure It, and Profit from It. (Updated ed.). Upper Saddle River: FT Press.

[14] Deari, H., Kimmel, V., \& Lopez, P. (2008). Effects of cultural differences in international business and price negotiation.

[15] Earley, P. C., \& Ang, S. (2003). Cultural intelligence: Individual interactions across cultures: Stanford University Press.

[16] Elashmawi, F. (2000). Cross-cultural negotiation. New Straits Times, 8.

[17] Gelfand, M. J., Erez, M., \& Aycan, Z. (2007). Cross-cultural organizational behavior. Annu. Rev. Psychol., 58, 479-514.

[18] Ghemawat, P., \& Reiche, S. (2011). National cultural differences and multinational business. Globalization note series, 11, 1-18.

[19] Heirsmac \& Agwu (2015). Impact of cross cultural factors on expatriates' effective execution of international assignments.

[20] Harvey \& Moeller (2009). Expatriate managers: A historical review, International Journal of Management Reviews, 11(3):275 - 296, DOI:10.1111/j.1468-2370.2009.00261.x

[21] Jatmiko, A. (2018). Sense of place and social anxiety relations of new comers of Raden Intan state Islamic University, Lampung. Al-Idarah: Jurnal Kependidikan Is/am, $8(1), 66-80$.

[22] Jyoti, J., \& Kour, S. (2015). Assessing the cultural intelligence and task performance equation: Mediating role of cultural adjustment. Cross Cultural Management, 22(2), 236-258.

[23] Lee, L.Y., \& Sukoco, B. M. (2010). The effects of cultural intelligence on expatriate performance: The moderating effects of international experience. The International Journal of Human Resource Management, 21(7), 963-981.

[24] Lee, H. A. (2016). Discrimination of high degrees: race and graduate hiring in Malaysia, Journal of the Asia Pacific Economy

[25] Miles, M. B., Huberman, A. M., \& Saldan冈a, J. (2014). Qualitative Data Analysis. A Methods Sourcebook. Los Angeles, London, New Delhi, Singapore, Washington DC: SAGE Publications.

[26] Muniapan, B. (2015). Labour Relations and International Business: The Doctrine of Constructive Dismissal and Labour Relations in Malaysia, In Beyond the UN Global Compact: Institutions and Regulations (Advances in Sustainability and Environmental Justice, Volume 17). Emerald Group Publishing Limited, pp.291 - 315.

[27] Ng, K.Y., \& Earley, P. C. (2006). Culture+ intelligence: Old constructs, new frontiers. Group \& Organization Management, 31(1), 4-19. 
[28] Ng, T. K., Wang, K. W. C., \& Chan, W. (2017). Acculturation and cross-cultural adaptation: The moderating role of social support. International journal of intercultural relations, 59, 19-30.

[29] Ramalu, S. S., Rose, R. C., Uli, J., \& Kumar, N. (2012). Cultural intelligence and expatriate performance in global assignment: The mediating role of adjustment. International Journal of Business and Society, 13(1), 19.

[30] Ramlan, S., Abashah, A., Samah, I., Rashid, I., \& Radzi, W. (2018). The impact of language barrier and communication style in organizational culture on expatriate's working performance. Management Science Letters, 8(6), 659-666.

[31] Rose, R. C., Ramalu, S. S., Uli, J., \& Kumar, N. (2010). Expatriate performance in international assignments: The role of cultural intelligence as dynamic intercultural competency. International Journal of Business and Management, 5(8), 76.

[32] Rostamzadeh, M., Anantharaman, R., \& Tong, D. Y. K. (2012). Sense of place on expatriate mental health in Malaysia. International Journal of Social Science and Humanity, 2(5), 360.

[33] Shafiq, M., \& Qureshi, M. I. (2014). Quadruple culture type approaches impacting employees attributes. Journal of Management Info, 1(2), 1-11.

[34] Shephard, P. (1996). Working with Malaysians: expatriates' and Malaysians Perspectives. Understanding the Malaysian Workforce-guidelines for managers, 1, 144-155.

[35] Skarzynski, P., \& Gibson, R. (2008). Innovation to the core: A blueprint for transforming the way your company innovates. Boston, MA: Harvard Business School Press

[36] Stake, R. (1995). The art of case study research (pp. 49-68). Thousand Oaks, CA: Sage.

[37] Stone-Romero, E. F., Stone, D. L., \& Salas, E. (2003). The influence of culture on role conceptions and role behavior in organisations. Applied psychology, 52(3), 328-362.

[38] Tahir, A. H. M., \& Ismail, M. (2007). Cross-cultural challenges and adjustments of expatriates: A case study in Malaysia. Alternatives: Turkish Journal of International Relations, 6(3\&4).

[39] Wang, H. C., Fussell, S. F., \& Setlock, L. D. (2009). Cultural difference and adaptation of communication styles in computer-mediated group brainstorming. Paper presented at the Proceedings of the SIGCHI Conference on Human Factors in Computing Systems.

[40] Ward, C., Bochner, S., \& Furnham, A. (2005). The psychology of culture shock: Routledge. 
[41] Ward, C., Fischer, R., Zaid Lam, F. S., \& Hall, L. (2009). The convergent, discriminant, and incremental validity of scores on a self-report measure of cultural intelligence. Educational and Psychological Measurement, 69(1), 85-105.

[42] Ward, C., \& Rana-Deuba, A. (2000). Home and host culture influences on sojourner adjustment. International journal of intercultural relations, 24(3), 291-306.

[43] Warren, S. (2017). An investigation of relationship correlates and predictors of cultural adjustment among missionaries.

[44] Zaman, K., Qureshi, M., \& Bhatti, M. (2011). The impact of culture and gender on leadership behavior: Higher education and management. Management Science Letters, 1(4), 531-540. 